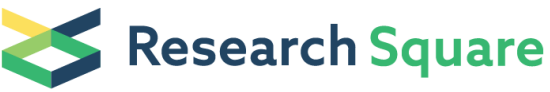 \\ Preprints are preliminary reports that have not undergone peer review. \\ They should not be considered conclusive, used to inform clinical practice, or referenced by the media as validated information.
}

\section{B7-H4 Expression is Upregulated by PKC $\delta$ Activation and Contributes to PKCס-Induced Cell Mobility in Colorectal Cancer}

\section{Bin Zhou}

Soochow University Affiliated No 1 Peoplel's Hospital: First Affiliated Hospital of Soochow University

Youwei Lu

Soochow University

\section{Zhiming Zhao}

Soochow University

\section{Tongguo Shi}

Soochow University Affiliated No 1 Peoplel's Hospital: First Affiliated Hospital of Soochow University Hongya Wu

Soochow University Affiliated No 1 Peoplel's Hospital: First Affiliated Hospital of Soochow University

\section{Weichang Chen}

Soochow University Affiliated No 1 Peoplel's Hospital: First Affiliated Hospital of Soochow University

\section{Liang Zhang ( $\nabla$ zliang@suda.edu.cn )}

Soochow University https://orcid.org/0000-0002-5041-8005

\section{Xueguang Zhang}

Soochow University Affiliated No 1 Peoplel's Hospital: First Affiliated Hospital of Soochow University

\section{Research Article}

Keywords: $\mathrm{B} 7-\mathrm{H} 4, \mathrm{PKC \delta}$, regulation, metastasis, colorectal cancer

Posted Date: July 16th, 2021

DOI: https://doi.org/10.21203/rs.3.rs-697909/v1

License: (c) (1) This work is licensed under a Creative Commons Attribution 4.0 International License. Read Full License 


\section{Abstract}

Background B7-H4 is overexpressed in colorectal cancer (CRC) and plays important roles in tumour growth and immunosuppression. However, the exact mechanism that regulates B7-H4 expression remains largely unknown. Protein kinase $\delta$ (PKC $\delta$ ) plays a significant role in a range of cancers, including CRC. Here, we investigated whether $\mathrm{PKC \delta}$ regulates the expression of $\mathrm{B} 7-\mathrm{H} 4$ in $\mathrm{CRC}$.

Methods By using immunohistochemical and immunofluorescence (IF) staining, we analysed the expression of B7-H4 and phospho-PKC $\delta$ (p-PKCס) in 225 colorectal tumour samples, and the clinical significance of these expression patterns was determined. In vitro experiments were performed with the CRC cell lines HCT116 and SW620 to detect the effect of PKCS activation on B7-H4 expression.

Results B7-H4 expression was significantly correlated with $\mathrm{p}-\mathrm{PKC} \delta$ expression $(\mathrm{r}=0.378, P<0.001)$ in tumour tissues. The co-expression of p-PKC $\delta$ and $\mathrm{B} 7-\mathrm{H} 4$ was significantly associated with moderate/poor differentiation $(P=0.024)$, lymph node metastasis $(P=0.001)$ and an advanced Dukes' stage $(P=0.002)$. Western blot analysis showed that TPA increased B7-H4 levels in a concentration-dependent manner and rottlerin also abrogated TPA-induced B7-H4 enhancement. The expression of B7-H4 and p-STAT3 were significantly reduced by PKC 8 -specific siRNA. Moreover, STAT3 inhibitor cryptotanshinone significantly decreased B7-H4 protein levels in HCT116 cells. Knockdown of B7-H4 or PKCס expression suppressed cell migration and mobility.

Conclusion B7-H4 expression was significantly correlated with p-PKC expression in CRC samples. B7-H4 expression

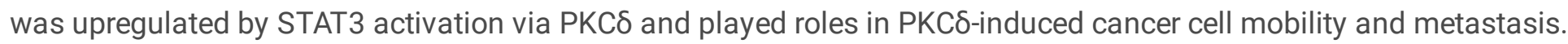

\section{Introduction}

Each year about 30,000 new cases of colorectal cancer (CRC) happened, which is the third most common cancer in the world. CRC leads to 13,000 deaths each year, which is the fourth cancer-related mortality.[1,2]. Although advances in early diagnosis and therapeutic strategies have decreased CRC mortality, the survival rate of CRC patients is still poor $[3,4]$. The high mortality rate is usually attributed to tumour recurrence and metastasis.

B7-H4 (VTCN1/B7x/B7S1) is a co-stimulatory molecule in the B7 family that has been found to be mainly expressed by antigen-presenting cells (APCs). Neutrophil progenitors could be suppressed by $\mathrm{B} 7-\mathrm{H} 4$ so that the host innate immune response is negatively regulated by $\mathrm{B} 7-\mathrm{H} 4$. Further, $\mathrm{T}$ cells also could be suppressed by $\mathrm{B} 7-\mathrm{H} 4$ so that the adaptive immune response is negatively regulated by $\mathrm{B} 7-\mathrm{H} 4$ [5-7]. In numerous tumour tissues $\mathrm{B} 7-\mathrm{H} 4$ is overexpressed and positively correlated with various clinicopathological factors, such as TNM stage, tumor-infiltrating T cell number and so on [8-12]. B7-H4 was significantly higher expressed in CRC tissues than in normal tissues and positively related to infiltration depth, lymph node metastasis and regulatory T cells (Treg) infiltration $[13,14]$. Further, soluble B7$\mathrm{H} 4$ in the serum has also been shown to be a potential biomarker for diseases [15-18]. In summary, B7-H4 plays dominant roles in tumour growth and immune evasion, but the exact mechanism that regulates $\mathrm{B} 7-\mathrm{H} 4$ expression remains largely unknown.

Protein kinase C (PKC) family, composed of a series of serine/threonine kinases, regulates various cellular physiological processes $[19,20]$. Increasing evidence shows that PKCs play an important role in CRC development [21-24]. As a unique novel PKC, PKCס plays a significant role in a range of cancers has different cell-specific effects [25-27]. PKCס is proposed to act mainly as a tumour suppressor due to its antiproliferative and proapoptotic activities. However, it is found that downregulation of PKC could induce cytotoxicity and inhibit the growth stem-like cell cultures originated from human breast, pancreatic and prostate cancer $[26,28]$. In colon cancer cells, PKC can inhibit 
cell growth and proliferation, and it also acts as a proapoptotic regulator in these cells $[29,30]$. Remarkably, PKC $\delta$ levels are elevated in colorectal cancer tissue, thus suggesting an extraordinary role for PKC $\delta$ in colon carcinogenesis [31-33]. Furthermore, PKCס is involved in colon cancer cell migration and invasion [32, 34-36].

In this study, we demonstrated the positive correlation between B7-H4 and p-PKC $\delta$ in clinical CRC samples. Further, the $\mathrm{p}-\mathrm{PKC} \delta^{+} \mathrm{B} 7-\mathrm{H}_{4}^{+}$phenotype was associated with tumour metastasis. To verify this finding in clinical samples, we investigated the effect of PKC $\delta$ on $\mathrm{B} 7-\mathrm{H} 4$ expression. PKC $\delta$ was activated by TPA but interfered with by PKC $\delta$-specific small interfering RNA (siRNA) in colorectal cancer cell lines. PKCD activation enhanced B7-H4 expression. Furthermore, both PKC 8 and B7-H4 played roles in cell mobility. Knockdown of B7-H4 could abrogate PKC $\delta$-induced cell metastasis, verified that $\mathrm{B} 7-\mathrm{H} 4$ contributed to $\mathrm{PKC} \delta$-induced cell metastasis and invasion.

\section{Materials And Methods}

2.1 Clinical samples The First Affiliated Hospital of Soochow University (Suzhou, China) approved our experimental protocols. A total of 225 colon cancer tissue specimens and 20 adjacent normal tissue specimens were obtained for immunohistochemistry $(\mathrm{IHC})$. Ethics of the clinical sample experiments was approved by the Institutional Review Board of Soochow University. Informed consent was also obtained from the patients for experimentation.

2.2 Immunohistochemistry and immunofluorescent staining For IHC analysis of p-PKC $\delta$, a rabbit anti-human monoclonal antibody for p-PKCס (phospho S299, ab133456) purchased fron Abcam was used in 1:100 dilution. For B7-H4 IHC staining, the mouse anti-human monoclonal antibody (clone 3C8) for B7-H4 was produced in our lab and used in 1:200 dilution [37]. For IF analysis, the secondary antibodies were Alexa Fluor 488-conjugated goat anti-rabbit IgG (1:100, Invitrogen) and Alexa Fluor 594-conjugated goat anti-mouse IgG (1:200, Invitrogen), respectively.

4- $\mu \mathrm{m}$ sections were cut from paraffin-embedded samples by a Leica microtome. Tissue microarrays were deparaffinized, rehydrated, rinsed, and stained for B7-H4 and p-PKCD, as previously described [38]. IHC staining was performed using the ChemMate ${ }^{\mathrm{TM}}$ Envision/HRP technique (Gene Tech Company Limited). According to the percentage of positive cells and the IHC staining intensity, the signals of B7-H4 or p-PKC $\delta$ were classified into four groups: negative, low, medium, or high. The Quickscore was defined as the product of the proportion and intensity scores. Cases for which the Quickscore was $\geq 4$ were considered positive, and the other cases were regarded as negative. The staining slides were examined and evaluated by two independent investigators.

For IF analysis, serial sections were incubated with anti-p-PKCס, anti-B7-H4 and/or an isotype IgG monoclonal antibodies for $1.5 \mathrm{~h}$ at room temperature, respectively. Alexa Fluor 488-conjugated secondary antibody was used to detect p-PKCס. Alexa Fluor 594-conjugated secondary antibody was used to detect B7-H4. IF images were observed under a Leica DM2500 microscope.

2.3 Cell culture and transfection The human CRC cell lines HCT116, SW620, SW480,RKO and NCM460 cells were purchased from Shanghai Cell Bank (Chinese Academy of Sciences, Shanghai). Cells were cultured in RPMI 1640 medium (HyClone) containing $10 \%$ fetal bovine serum (FBS, Gibco) at $37^{\circ} \mathrm{C}$ in a humidified atmosphere of $5 \% \mathrm{CO}_{2}$.

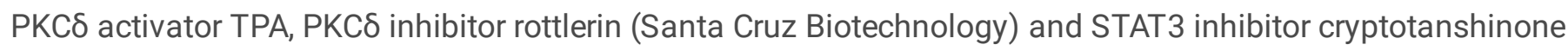
(Selleckchem) were stored at $-80^{\circ} \mathrm{C}$.

Human PKCס-specific siRNA, human B7-H4-specific siRNA and corresponding control siRNAs (con siRNAs) were purchased from GenePharma Co. Ltd (Shanghai, China). siRNA was transfected into HCT116 or SW620 cells using Lipofectamine 2000 reagent (invitrogen). RT-qPCR and Western blot were performed to examine the transfection efficiency. 
2.4 Total RNA isolation and RT-qPCR assays Total RNA was isolated using TRIzol reagent (Invitrogen). RNA was quantified with a spectrophotometer (BioDrop- $\mu$ Lite). Total RNA was reverse transcribed into cDNA using PrimeScript ${ }^{\mathrm{TM}}$ RT Master Mix (Takara Bio). SYBR PrimeScript RT-qPCR Kit was used (Takara Bio) to examine individual genes. The PCR procedure was performed as following: $95^{\circ} \mathrm{C}$ for $2 \mathrm{~min}, 45$ cycles amplification at $95^{\circ} \mathrm{C}$ for $10 \mathrm{~s}$, at $59^{\circ} \mathrm{C}$ for $40 \mathrm{~s}$ and at $72^{\circ} \mathrm{C}$ for $45 \mathrm{~s}$. All the genes examined was normalized to GAPDH mRNA level. The primers of individual genes used in RT-qPCR are listed in Supplemental Table 1.

2.5 Protein extraction and Western blot analysis Human CRC cell lines were cultured in 6-well plates and then lysed with RIPA lysis buffer (Beyotime). Protease inhibitor cocktail was added into the RIPA buffer. After determining the protein concentrations of all samples by BCA protein assay kits (Beyotime), each sample was loaded at equal amounts of total protein and separated by electrophoresis on $12 \%$ sodium dodecyl sulfate-polyacrylamide gel (SDS-PAGE). The protein bands on gel were transferred to a polyvinylidene difluoride (PVDF) membrane (Merck Millipore). The membranes were incubated with primary antibodies at $4^{\circ} \mathrm{C}$ overnight. The primary antibodies used were as follows: mouse anti-human B7-H4 (3C8), rabbit anti-human PKCס (CST, \#9616T), rabbit anti-human/mouse p-PKC (Abcam, ab133456), rabbit anti-human/ mouse STAT3 (CST, \#12640), rabbit anti-human/ mouse Phospho-STAT3 (p-STAT3, Tyr705) (CST, \#9145), rabbit anti-human/ mouse GAPDH (CST, \#5174) and rabbit anti-human/ mouse $\beta$-actin (CST, \#4970). After three times washing with PBST, the PVDF membranes were incubated with secondary antibodies at room temperature for $2 \mathrm{~h}$. The secondary antibodies were as follows: HRP-conjugated goat anti-mouse/anti-rabbit lgG (H + $\mathrm{L})$ (Thermo) and rabbit anti-goat IgG $(\mathrm{H}+\mathrm{L})$ (Thermo). The membranes were washed with PBST five times. Then, the membranes were immersed in electrochemiluminescence (ECL) detection reagent (CST). The images were captured by the Gel DocTM EZ System (Bio-Rad). Image Lab 4.0.1 software (Bio-Rad) was used to analyze the intensities of the bands.

2.6 Flow cytometry analysis and IF analysis To examine B7-H4 expression in HCT116, cells were first washed in PBS buffer containing 1\% FCS three times. Then cells were stained with a PE-conjugated anti-B7-H4 antibody (358104, Biolegend). PE-labelled mouse IgG1 isotype controls (eBioscience) were used as the control antibody. To examine the intracellular B7-H4 expression, cells were permeabilized using Intracellular Fixation \& Permeabilization Buffer (eBioscience). Flow cytometry was performed on a Beckman flow cytometer. Data were analyzed using FlowJo software (Version 7.6, Tree Star Inc.).

For IF analysis of B7-H4 expression in cells, cultured cells were fixed in cold acetone for 10 min, washed in PBS buffer containing $1 \%$ FCS, and stained with a PE-conjugated anti-B7-H4 antibody.

2.7 Cell Proliferation Assay Cell viability was assessed by Cell Counting Kit- (CCK-) 8 (Tongren, Shanghai, China). After $16 \mathrm{~h}$ of transfection, cells were digested and re-suspended in $2 \%$ FBS culture medium with a drug or vehicle, and $5 \times 10^{3}$ cells were seeded in each 96-well plate and further incubated for 24 hours, respectively. CCK-8 reagent was added to each well and further incubated 2 hours. Then the cells were determined by the optical density (OD) $450 \mathrm{~nm}$ values using a microplate reader. Experiments were repeated three times each time in triplicate.

2.8 Transwell invasion assay After $16 \mathrm{~h}$ of transfection, cells were digested and re-suspended in $10 \%$ FBS culture medium, and $5 \times 10^{4}$ cells were seeded in 24-well transwell chambers with a pore size of $8 \mu \mathrm{m}$ (FALCON), the inserts were pre-coated with $40 \mu \mathrm{L}$ 1: 4 dilution of Matrigel (Corning, USA). Each well of the culture medium was changed to $2 \%$ FBS culture medium with a drug or solvent after $6-8$ hours. Then, $700 \mu$ l of medium containing $20 \%$ FBS was added into the bottom chamber, acting as the chemoattractant. After cultured for $24 \mathrm{~h}$, the cells invaded to the underside of the transwell membrane were fixed in methanol and stained with a $0.1 \%$ crystal violet solution. Then the staining cells were observed under a Nikon TI-SR inverted microscope and imaged using a Nikon DS-Fi2 camera. Then 
cells were destained with $30 \%$ glacial acetic acid and the cell number was quantified by detecting OD $570 \mathrm{~nm}$ using a microplate reader.

2.9 Wound-healing assay For a wound-healing migration assay, 12-well plates were seeded with cells at a density of 3 $\times 10^{5} /$ well. After overnight growth and attachment, the cultured cells were scratched with $10-\mu l$ pipette tips. After the subsequent $24 \mathrm{~h}$ culture, wound closure was observed and imaged using a Nikon DS-Fi2 camera. The percentage of wound closure was calculated using Image J software.

2.10 Statistical analysis Statistical analyses of experimental results were performed with GraphPad Prism version 5.0. The associations between p-PKCס, B7-H4 and various clinicopathological parameters were evaluated by the $\chi^{2}$ test. Correlation was evaluated by the Spearman rank correlation coefficient. Differences between groups were evaluated using a two-tailed unpaired Student's t test. Replicated experiments were analyzed using a paired Student's t test. All significance tests were two sided, and $P<0.05$ was considered as significance.

\section{Results}

\subsection{The association between B7-H4 and p-PKC $\delta$ in CRC}

First, we evaluated B7-H4 and p-PKC expression by IHC in 225 clinical colorectal tumour tissue specimens and 20 adjacent normal tissue specimens. Representative IHC staining images are shown in Fig. $1 \mathrm{~A}$. Comparison of the tumour tissues and adjacent normal tissues revealed that both $\mathrm{B} 7-\mathrm{H} 4$ and p-PKC $\delta$ expression were significantly increased in the tumour tissue samples (Fig. 1B), which was consistent with previous reports [13, 31, 33]. Furthermore, quantitative PCR analysis also showed that both $\mathrm{B} 7-\mathrm{H} 4$ and PKC 8 were significantly increased in the tumour tissues as compared with the adjacent normal tissues (Fig. 1C).

In colorectal tumour tissue specimens, positive B7-H4 expression was detected in 132 cases (132/225, 58.7\%), and B7$\mathrm{H} 4$ was expressed in the membrane, cytoplasm and nucleus of colorectal tumour cells (Fig. 1A). Positive p-PKC expression was detected in 139 cases (139/225, 61.8\%), and p-PKC $\delta$ was expressed in the membrane and cytoplasm of colorectal tumour cells (Fig. 1A). Spearman analysis showed that B7-H4 expression was significantly correlated with p-PKCS expression $(r=0.378, P<0.001)$. Pearson chi-square analysis also showed that $\mathrm{B} 7-\mathrm{H} 4$ expression was significantly correlated with p-PKC $\delta$ expression $(P<0.001)$ (Table 1). Of the 139 p-PKC $\delta$-positive tumour samples, 101 cases $(72.7 \%, 101 / 139)$ showed positive B7-H4 expression, whereas of the 86 p-PKC 8 -negative tumour samples, only 31 cases $(36.0 \%, 31 / 86)$ showed positive B7-H4 expression. Then, we performed analysis of the TCGA colon adenocarcinoma (COAD) dataset on the GEPIA website (http://gepia.cancer-pku.cn/). This analysis showed that PRKCD (PKCD) mRNA level was positively correlated with VTCN1 (B7-H4 gene) mRNA level (Fig. 2A).

Table 1

The expression of $\mathrm{B} 7-\mathrm{H} 4$ and $\mathrm{p}-\mathrm{PKC}$ in clinical CRC tissues

\begin{tabular}{|c|c|c|c|}
\hline \multirow[t]{2}{*}{ p-PKCठ expression } & \multicolumn{2}{|c|}{ B7-H4 expression (\%) } & \multirow[t]{2}{*}{$p$ value $^{\mathrm{a}}$} \\
\hline & Negative $(\mathrm{n}=93)$ & Positive( $(n=132)$ & \\
\hline Negative $(n=86)$ & $55(64.0)$ & $31(36.0)$ & \multirow[t]{2}{*}{$0.000^{b}$} \\
\hline Positive $(n=139)$ & $38(27.3)$ & $101(72.7)$ & \\
\hline${ }^{a} p$ value is obtain & y Pearson chi-s & e, Asymp. Sig., tw & tailed. \\
\hline
\end{tabular}

Page 5/20 
To verify the finding that $\mathrm{B} 7-\mathrm{H} 4$ is correlated with $\mathrm{p}-\mathrm{PKC} \delta$ level in clinical samples, we examined $\mathrm{B} 7-\mathrm{H} 4$ and p-PKC $\delta$ levels in CRC cell lines. As shown in Fig. 2B and supplemental FigureS1, the B7-H4 protein level was higher in the HCT116 and SW620 cell lines, intermediate in the SW480 and RKO cell lines, and lower in the NCM460 cell line. Consistently, p-PKC $\delta$ expression was also higher in HCT116 and SW620 cells than in other cells, verifying the correlation between the p-PKC $\delta$ and B7-H4 protein levels in CRC cell lines.

Altogether, the results obtained from the clinical CRC samples and CRC cell lines showed that B7-H4 expression was correlated with p-PKC $\delta$ expression in CRC.

\subsection{Co-expression of B7-H4 with p-PKCס in clinical CRC tissue samples}

As we found that B7-H4 expression was significantly correlated with $\mathrm{p}-\mathrm{PKC} \delta$ expression, we further investigated whether they are co-expressed in $\mathrm{CRC}$ tissue. Serial sections of $\mathrm{p}-\mathrm{PKC} \delta^{+} \mathrm{B} 7-\mathrm{H} 4^{+} \mathrm{CRC}$ samples were stained successively as follows: IHC staining for p-PKCD, IHC staining for B7-H4, and IF double staining for p-PKCD and B7-H4.

Representative images of stained sections are shown in Fig. 2C. IHC staining showed that the positive staining areas were similar for the two molecules. Merged images of IF double staining showed that the green and red fluorescence overlapped. Both IHC staining and IF staining demonstrated that $\mathrm{p}-\mathrm{PKC} \delta$ and $\mathrm{B} 7-\mathrm{H} 4$ were co-expressed in CRC tissue samples.

The results of the serial CRC sample staining further indicated that B7-H4 expression in CRC tissue was correlated with activated PKCठ expression.

\subsection{B7-H4 and p-PKCס expression was associated with tumour metastasis in CRC samples}

Next, we examined the associations of B7-H4 and p-PKCס with clinical parameters. As shown in Table 2, among 225 CRC samples, positive B7-H4 expression was correlated with moderate/poor differentiation $(\chi 2=8.992, P=0.003)$, lymph node metastasis $(\chi 2=8.919, P=0.003)$ and an advanced Dukes' stage $(\chi 2=5.427, P=0.02)$, and positive $p$ PKCס expression was correlated with an advanced Dukes' stage $(\chi 2=4.118, P=0.042)$. Notably, the co-expression of B7-H4 and p-PKCS was significantly associated with moderate/poor differentiation $(\chi 2=5.072, P=0.024)$, lymph node metastasis $(X 2=10.909, P=0.001)$ and an advanced Dukes' stage $(\chi 2=10.017, P=0.002)$. TCGA COAD dataset analysis on the XENA website showed that the B7-H4 mRNA level was also positively correlated with lymph node metastasis (Fig. 2D). The results suggested that $\mathrm{B} 7-\mathrm{H} 4$ and $\mathrm{p}-\mathrm{PKC} \delta$ were associated with tumour metastasis. 
Table 2

The association of B7-H4 and p-PKCס with clinical parameters

\begin{tabular}{|c|c|c|c|c|c|c|c|c|c|}
\hline \multirow[t]{2}{*}{ Variables } & \multicolumn{3}{|l|}{ B7-H4(\%) } & \multicolumn{3}{|c|}{ p-PKCס (\%) } & \multicolumn{3}{|c|}{ p-PKCS+B7-H4+ (\%) } \\
\hline & $\begin{array}{l}\text { Positive } \\
(n= \\
132)\end{array}$ & $\begin{array}{l}\text { Negative } \\
(n=93)\end{array}$ & $\begin{array}{l}P \\
\text { value }^{a}\end{array}$ & $\begin{array}{l}\text { Positive } \\
(n= \\
139)\end{array}$ & $\begin{array}{l}\text { Negative } \\
(n=86)\end{array}$ & $\begin{array}{l}P \\
\text { value }^{\mathrm{a}}\end{array}$ & $\begin{array}{l}\text { Positive } \\
(\mathrm{n}= \\
101)\end{array}$ & $\begin{array}{l}\text { Others } \\
(n= \\
124)\end{array}$ & $\begin{array}{l}P \\
\text { value }^{\mathrm{a}}\end{array}$ \\
\hline \multicolumn{10}{|l|}{ Gender } \\
\hline Male $(n=122)$ & $\begin{array}{l}72 \\
(59.0 \%)\end{array}$ & $\begin{array}{l}50 \\
(41.0 \%)\end{array}$ & 0.908 & $\begin{array}{l}78 \\
(63.9 \%)\end{array}$ & $\begin{array}{l}44 \\
(36.1 \%)\end{array}$ & 0.469 & $\begin{array}{l}53 \\
(43.4 \%)\end{array}$ & $\begin{array}{l}69 \\
(56.6 \%)\end{array}$ & 0.635 \\
\hline $\begin{array}{l}\text { Female }(n= \\
103)\end{array}$ & $\begin{array}{l}60 \\
(58.3 \%)\end{array}$ & $\begin{array}{l}43 \\
(41.7 \%)\end{array}$ & & $\begin{array}{l}61 \\
(59.2 \%)\end{array}$ & $\begin{array}{l}42 \\
(40.8 \%)\end{array}$ & & $\begin{array}{l}48 \\
(46.6 \%)\end{array}$ & $\begin{array}{l}55 \\
(53.4 \%)\end{array}$ & \\
\hline \multicolumn{10}{|l|}{ Histology } \\
\hline Well $(n=36)$ & $\begin{array}{l}13 \\
(36.1 \%)\end{array}$ & $\begin{array}{l}23 \\
(63.9 \%)\end{array}$ & $0.003^{b}$ & $\begin{array}{l}22 \\
(61.1 \%)\end{array}$ & $\begin{array}{l}14 \\
(38.9 \%)\end{array}$ & 0.928 & $\begin{array}{l}10 \\
(27.8 \%)\end{array}$ & $\begin{array}{l}26 \\
(72.2 \%)\end{array}$ & $\begin{array}{l}0.024 \\
b\end{array}$ \\
\hline $\begin{array}{l}\text { Moderate/Poor } \\
(n=189)\end{array}$ & $\begin{array}{l}119 \\
(63.0 \%)\end{array}$ & $\begin{array}{l}70 \\
(37.0 \%)\end{array}$ & & $\begin{array}{l}117 \\
(61.9 \%)\end{array}$ & $\begin{array}{l}72 \\
(38.1 \%)\end{array}$ & & $\begin{array}{l}91 \\
(48.1 \%)\end{array}$ & $\begin{array}{l}98 \\
(51.9 \%)\end{array}$ & \\
\hline \multicolumn{10}{|l|}{ Depth of tumor } \\
\hline $\begin{array}{l}T 1+T 2(n= \\
51)\end{array}$ & $\begin{array}{l}26 \\
(51 \%)\end{array}$ & $\begin{array}{l}25 \\
(49 \%)\end{array}$ & 0.205 & $\begin{array}{l}31 \\
(52.6 \%)\end{array}$ & $\begin{array}{l}20 \\
(47.4 \%)\end{array}$ & 0.868 & $\begin{array}{l}19 \\
(15.8 \%)\end{array}$ & $\begin{array}{l}32 \\
(84.2 \%)\end{array}$ & 0.213 \\
\hline $\begin{array}{l}T 3+T 4(n= \\
174)\end{array}$ & $\begin{array}{l}106 \\
(60.9 \%)\end{array}$ & $\begin{array}{l}68 \\
(39.1 \%)\end{array}$ & & $\begin{array}{l}108 \\
(69.1 \%)\end{array}$ & $\begin{array}{l}66 \\
(30.9 \%)\end{array}$ & & $\begin{array}{l}82 \\
(47.1 \%)\end{array}$ & $\begin{array}{l}92 \\
(52.9 \%)\end{array}$ & \\
\hline \multicolumn{10}{|l|}{$\begin{array}{l}\text { Lymph node } \\
\text { metastasis }\end{array}$} \\
\hline $\begin{array}{l}\text { Negative }(n= \\
136)\end{array}$ & $\begin{array}{l}69 \\
(50.7 \%)\end{array}$ & $\begin{array}{l}67 \\
(49.3 \%)\end{array}$ & $0.003^{b}$ & $\begin{array}{l}79 \\
(58.1 \%)\end{array}$ & $\begin{array}{l}57 \\
(41.9 \%)\end{array}$ & 0.159 & $\begin{array}{l}49 \\
(36.0 \%)\end{array}$ & $\begin{array}{l}87 \\
(64.0 \%)\end{array}$ & $0.001^{b}$ \\
\hline $\begin{array}{l}\text { Positive }(n= \\
89)\end{array}$ & $\begin{array}{l}63 \\
(70.8 \%)\end{array}$ & $\begin{array}{l}26 \\
(29.2 \%)\end{array}$ & & $\begin{array}{l}60 \\
(67.4 \%)\end{array}$ & $\begin{array}{l}29 \\
(32.6 \%)\end{array}$ & & $\begin{array}{l}52 \\
(58.4 \%)\end{array}$ & $\begin{array}{l}37 \\
(41.6 \%)\end{array}$ & \\
\hline \multicolumn{10}{|l|}{ Dukes'stage } \\
\hline$A+B(n=122)$ & $\begin{array}{l}63 \\
(51.6 \%)\end{array}$ & $\begin{array}{l}59 \\
(48.4 \%)\end{array}$ & $0.020^{\mathrm{b}}$ & $\begin{array}{l}68 \\
(55.7 \%)\end{array}$ & $\begin{array}{l}54 \\
(44.3 \%)\end{array}$ & $0.042^{b}$ & $\begin{array}{l}43 \\
(35.2 \%)\end{array}$ & $\begin{array}{l}79 \\
(64.8 \%)\end{array}$ & $0.002^{b}$ \\
\hline$C+D(n=103)$ & $\begin{array}{l}69 \\
(67.0 \%)\end{array}$ & $\begin{array}{l}34 \\
(33.0 \%)\end{array}$ & & $\begin{array}{l}71 \\
(68.9 \%)\end{array}$ & $\begin{array}{l}32 \\
(31.1 \%)\end{array}$ & & $\begin{array}{l}58 \\
(56.3 \%)\end{array}$ & $\begin{array}{l}45 \\
(43.7 \%)\end{array}$ & \\
\hline \multicolumn{10}{|c|}{ a $p$ value is obtained by Pearson chi-square, Asymp. Sig., two tailed. } \\
\hline
\end{tabular}

\subsection{Activated PKCO induced B7-H4 expression in CRC cell lines}

As a classic activator of PKCs, TPA can induce strong PKC $\delta$ allocation mainly to the plasma membrane [32]. We examined the effect of TPA on B7-H4 expression in CRC cell lines. HCT116 and SW620 cells were treated with various concentrations of TPA for $20 \mathrm{~h}$, and the B7-H4 protein levels were determined by Western blot. TPA increased B7-H4 protein levels in a concentration-dependent manner in the two cell lines (Fig. 3A and supplemental FigureS2A). B7-H4 and nuclei in the HCT116 cell line were immunofluorescently stained, and stained cells were observed under a confocal 
microscope (Fig. 3B). The results showed that $48 \mathrm{~h}$ of TPA $(100 \mathrm{nM})$ treatment significantly increased the percentage of $\mathrm{B} 7-\mathrm{H}_{4}^{+}$cells. Furthermore, cell lines were treated with rottlerin, a PKC $\delta$ inhibitor. The results showed that rottlerin effectively decreased B7-H4 protein levels in a concentration-dependent manner in the HCT116 and SW620 cell lines (Fig. 3C and supplemental FigureS2B). Flow cytometry analysis also demonstrated that TPA increased B7-H4 expression and rottlerin decreased B7-H4 expression in the HCT116 cell line (Fig. 3D). Then, the HCT116 and SW620 cell lines were first treated with $1 \mu \mathrm{M}$ rottlerin and subsequently treated with $100 \mathrm{nM}$ TPA. This experiment showed that rottlerin could effectively abrogate TPA-induced B7-H4 enhancement (Fig. 3E and supplemental FigureS2C).

\subsection{PKCס knockdown inhibited B7-H4 expression in CRC cell lines}

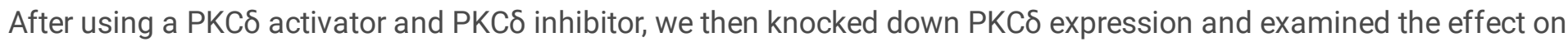
B7-H4 expression in CRC cell lines. PKC $\delta$ mRNA was knocked down in HCT116 and SW620 cells as described in the Methods. The PKC $\delta$ mRA levels were decreased dramatically in the treated group compared with the mock group (Fig. 4A). Western blot analysis showed that the PKCD and B7-H4 protein levels were significantly decreased in the PKCD siRNA/HCT116 and PKCס siRNA/SW620 cell lines (Fig. 4B and supplemental FigureS3A). The con siRNA/HCT116 and PKCס siRNA/HCT116 cell lines were treated with TPA, and PKC $\delta$ knockdown abrogated TPAinduced B7-H4 enhancement (Fig. 4C and supplemental FigureS3B).

Taken together, these data suggested that PKC $\delta$ knockdown could downregulate B7-H4 expression in CRC cells.

\subsection{PKCס controlled B7-H4 expression via STAT3}

We next explored the signaling pathway by which PKCס mediated the expression of B7-H4. Previous study has shown that activated STAT3 could bind to the B7-H4 promoter and enhance the expression of B7-H4 protein in microglia cells [39]. In addition, PKCס is known to be a primary regulator of STAT3 phosphorylation in keratinocytes and luteal cells $[40,41]$. Therefore, we hypothesized that activated PKC $\delta$ could induce B7-H4 expression by increasing phosphorylation of STAT3 in CRC cells. Western blot analysis showed that B7-H4 and p-STAT3 were decreased in the PKCD siRNA/HCT116 cells (Fig. 4D and supplemental FigureS3C). Moreover, we observed that cryptotanshinone, a STAT3 phosphorylation inhibitor, which significantly decreased B7-H4 protein levels in a concentration-dependent manner in HCT116 cells (Fig. 4E and supplemental FigureS3D). These results suggest that PKC $\delta$ could regulate the expression of B7-H4 by the STAT3 signaling pathway in CRC cells.

\subsection{The PKC8/B7-H4 axis promotes the mobility of CRC cell lines}

As the clinical sample and dataset analyses showed that B7-H4 and p-PKC $\delta$ were associated with CRC metastasis, we further examined whether the PKCס/B7-H4 axis mediates HCT116 cell invasion and migration. Previously, the PKC siRNA/HCT116 cell line was constructed. Here, we constructed the B7-H4 siRNA/HCT116 cell line (Fig. 5A and supplemental FigureS4). A transwell experiment showed that knockdown of B7-H4 or PKC 8 expression inhibited the constitutive invasion of HCT116 cells (Fig. 5B), suggesting that B7-H4 and PKC 8 promoted cell mobility. And we found that pharmacological promotion of PKCס expression with $24 \mathrm{~h}$ of TPA treatment effectively enhanced cell invasion (Fig. 5C). However, knockdown of B7-H4 prevented the enhancement in invasion (Fig. 5C), suggesting that B7-H4 plays a role in $\mathrm{PKC} \delta$ activation-induced cell invasion.

To evaluate the effects of PKCס and B7-H4 on cell migration, we performed a wound-healing experiment. Images showing wound closure are shown in Fig. 5D. Knockdown of PKCठ or B7-H4 expression effectively inhibited cell mobility. TPA treatment effectively enhanced the mobility of the consiRNA/HCT116 cell line, but the effect was obviously reduced in B7-H4 siRNA/HCT116 and PKC siRNA/HCT116 cells. The cells viability was also assessed as 
the condition of wound-healing experiment. There are no different between the TPA treatment groups and control groups (Fig. 5E).

\section{Discussion}

CRC cell migration and invasion often are related to the occurrence of postsurgical metastasis and poor survival in CRC patients, so we need to find new CRC therapies to block metastasis. Previous studies revealed that PKC $\delta$ is involved in colon cancer cell migration and invasion. PKC is involved in the cell migration-associated IGF-I signalling pathway [34]. PKCס can also enhance the migration and invasiveness of colon carcinoma cells by enhancing KITENIN protein expression, HuR phosphorylation and Trop-2 phosphorylation [32, 33, 36]. Knockdown B7-H4 effectively inhibits the proliferation, invasion, and migration of CRC cells, gastric cancer cells and lung cancer cells via various signalling pathways [42-44]. Both $\mathrm{PKC} \delta$ and $\mathrm{B} 7-\mathrm{H} 4$ contribute to tumour metastasis; therefore, we wanted to investigate the correlation among PKCס, B7-H4 and metastasis in CRC.

As a member of the novel PKC family, PKC $\delta$ can be activated independent of $\mathrm{Ca}^{2+}$ and phospholipids and has multiple functions associated with cancer progression, including functions in the proliferation, survival, apoptosis and motility of cancer cells [27]. In colon cancer cells, PKC can inhibit cell growth and proliferation and act as a proapoptotic regulator. Interestingly, in contrast to many human cancers showing decreased PKC $\delta$ expression with increasing tumour grade, colorectal cancer tissues show increased PKC $\delta$ levels, thus pointing to an extraordinary role for PKC $\delta$ in colon carcinogenesis [32]. We also found that p- PKCD level was increased in some CRC cell lines (Fig. 1), but the function and mechanisms of PKC $\delta$ in CRC remain to be elucidated. Therefore, we monitored the expression of $p$ - PKC $\delta$ and $\mathrm{B} 7-\mathrm{H} 4$ in tumour cells and found that $\mathrm{p}-\mathrm{PKC} \delta$ was overexpressed in some colorectal tumour samples (139/225, $61.8 \%)$. IHC of serial sections from identical tissues showed that $101 \mathrm{p}-\mathrm{PKC}^{+}$samples also expressed $\mathrm{B} 7-\mathrm{H} 4$ (72.7\%, $101 / 139)$, and IF staining results further confirmed this observation. IHC results showed that $\mathrm{p}-\mathrm{PKC} \delta^{+} \mathrm{B} 7-\mathrm{H} 4^{+}$ colorectal tumour samples were significantly associated with moderate/poor differentiation $\left(\chi^{2}=5.072, P=0.024\right)$, lymph node metastasis $\left(\chi^{2}=10.909, P=0.001\right)$ and an advanced Dukes' stage $\left(\chi^{2}=10.017, P=0.002\right)$. Thus, we speculated that the magnitude of $\mathrm{PKC} \delta$ activation is related to $\mathrm{B} 7-\mathrm{H} 4$ levels and plays an important role in cancer progression.

It is reported that $\mathrm{B} 7-\mathrm{H} 4$ expression can be upregulated by many inflammatory mediators. In a renal cell carcinoma cell line, IFN-a, IL-2, and IFN-y upregulate B7-H4 expression [45]. In human ovarian cancer and glioma cancer, tumourassociated Tregs trigger macrophages to secrete IL-10 and IL-6, which activate Stat3 and induce B7-H4 transcription $[46,47]$. In human lung cancer, tumour-associated macrophages secreted TNF-a, IL-10, and IFN- $\gamma$, which induce B7-H4 expression in lung cancer cells [48]. Our previous study revealed that B7-H4 can be upregulated by IGF1R activation through the MEK/ERK1/2 signalling pathway in lung cancer [49]. In multiple myeloma, hypoxia could upregulate B7-H4 expression, chromatin immunoprecipitation analysis convinced hypoxia-inducible factor-1a (HIF-1a) could bind to B7H4 promoter and induced B7-H4 expression[50]. The NF-KB (P65) pathway could also increase PD-L1 and B7-H4 levels in hepatocellular carcinoma (HCC) tissues [51]. A recent study demonstrated that TGF- $\beta 1$-driven SMAD3/4 signalling can increase B7-H4 expression in colorectal cancer [52]. Most of these studies found the triggering factors contributing B7-H4 expression, but the exact signalling pathways involved in the regulation of B7-H4 expression still require further elucidation.

In this study, we found that $\mathrm{p}-\mathrm{PKC}$ and $\mathrm{B} 7-\mathrm{H} 4$ protein expression was higher in $\mathrm{CRC}$ cell lines than in a normal cell line. PKC activator TPA increased the B7-H4 levels in the CRC cell lines HCT116 and SW620 in a concentrationdependent manner. Rottlerin, an inhibitor of PKC8, decreased B7-H4 expression and abrogated TPA-induced B7-H4 enhancement. PKCס-specific siRNA also effectively decreased B7-H4 levels and abrogated TPA-induced B7-H4 
enhancement. All these results verified the findings reported for clinical samples and confirmed that B7-H4 expression

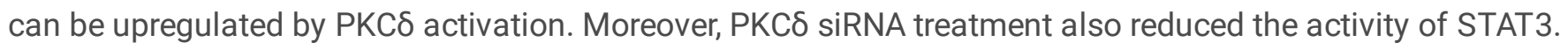
Importantly, STAT3 inhibitor cryptotanshinone significantly decreased B7-H4 protein levels in a concentrationdependent manner in HCT116 cells. These results suggest that PKC $\delta$ could regulate the expression of B7-H4 via STAT3. We also observed that PKC $\delta$ promoted B7-H4 expression through MEK/ERK1/2 pathway in CRC cells, but we didn't find the change (data not shown). Several studies have suggested that PKC $\delta$ plays a role in colon cancer migration and invasion. Here, we also performed transwell invasion and wound-healing assays to detect the motility of HCT116 cells. We found that knockdown of B7-H4 or PKC $\delta$ suppressed cell motility and suppressed TPA-enhanced cell invasion and migration.

In conclusion, our results identify a canonical PKCD/STAT3/B7-H4 signaling pathway that is constitutively active in colorectal carcinoma cells. B7-H4 expression was upregulated by PKC $\delta$ activation and contributed to PKC $\delta$-induced cell motility, which plays a role in the immune escape of CSCs. This result suggests that B7-H4 and PKC $\delta$ may be therapeutic targets in tumour metastasis. It might be important to consider the effect on B7-H4 when a PKC $\delta$ inhibitor is used clinically.

\section{Abbreviations}

\section{CRC}

colorectal cancer

PKC

Protein kinase $\mathrm{C}$

APCs

antigen-presenting cells

Treg

regulatory $\mathrm{T}$ cells

\section{siRNA}

small interfering RNA

IHC

Immunohistochemistry

IF

immunofluorescence

FBS

fetal bovine serum

\section{SDS-PAGE}

sodium dodecyl sulfate-polyacrylamide gel

PVDF

polyvinylidene difluoride

FCS

Flow cytometry analysis

HIF-1a

hypoxia-inducible factor-1a

HCC

hepatocellular carcinoma

\section{Declarations}


Availability of data and materials

The datasets generated during the current study can be discovered in online repositories, further inquiries can be available from the corresponding author.

\section{Acknowledgements}

Not applicable.

\section{Funding}

This work was funded by grants from Jiangsu Province's Key Discipline/Laboratory of Medicine (China), the Natural Science Foundation of China (No. 81502454 and No. 81273242), the Major International (Regional) Joint Research Project (No. 31320103918) and the Defense Basic Research Projects.

\section{Author information}

Bin Zhou and Youwei Lu contributed equally to this work

\section{Contributions}

Xueguang Zhang and Liang Zhang designed research; Bin Zhou, Youwei Lu, Zhiming Zhao and Hongya Wu performed research; Bin Zhou, Tongguo Shi and Weichang Chen contributed to data analysis and interpretation; Bin Zhou and Liang Zhang wrote the paper.

\section{Corresponding authors}

Correspondence to Xueguang Zhang or Liang Zhang.

\section{Ethics declarations}

Ethics approval and consent to participate This work obtained ethics approval by The First Affiliated Hospital of Soochow University, reference number 2014865082. All patients included were consented to participate in the study and to use their materials in research.

Consent for publication Not applicable.

Competing interests The authors declare that they have no conflict of interest.

\section{References}

1. Morris EJ, Forman D, Thomas JD, Quirke P, Taylor EF, Fairley L, et al. Surgical management and outcomes of colorectal cancer liver metastases. Br J Surg. 2010;97(7):1110-8.

2. Xu G, Zhou Y, Zhou F. Development and validation of an immunity-related classifier of nine chemokines for predicting recurrence in stage I-III patients with colorectal cancer after operation. Cancer Manag Res. 2018;10:4051-64.

3. Levin B, Lieberman DA, McFarland B, Andrews KS, Brooks D, Bond J, et al. Screening and surveillance for the early detection of colorectal cancer and adenomatous polyps, 2008: a joint guideline from the American Cancer Society, the US Multi-Society Task Force on Colorectal Cancer, and the American College of Radiology. Gastroenterology. 2008;134(5):1570-95. 
4. Han EC, Kwon Y-H, Park KJ, Jeong S-Y, Kang S-B, Oh JH, et al. Significance of lymph node metastasis in the survival of stage IV colorectal cancer by hematogenous metastasis. Annals of surgical treatment research. 2018;95(4):201-12.

5. Zang X, Loke P, Kim J, Murphy K, Waitz R, Allison JP. B7x: a widely expressed B7 family member that inhibits T cell activation. Proc Natl Acad Sci U S A. 2003;100(18):10388-92.

6. Sica GL, Choi IH, Zhu G, Tamada K, Wang SD, Tamura H, et al. B7-H4, a molecule of the B7 family, negatively regulates T cell immunity. Immunity. 2003;18(6):849-61.

7. $\mathrm{He} \mathrm{C}$, Qiao $\mathrm{H}$, Jiang $\mathrm{H}$, Sun $\mathrm{X}$. The inhibitory role of b7-h4 in antitumor immunity: association with cancer progression and survival. Clin Dev Immunol. 2011;2011:695834.

8. Krambeck AE, Thompson RH, Dong H, Lohse CM, Park ES, Kuntz SM, et al. B7-H4 expression in renal cell carcinoma and tumor vasculature: associations with cancer progression and survival. Proc Natl Acad Sci U S A. 2006;103(27):10391-6.

9. Zang X, Thompson RH, Al-Ahmadie HA, Serio AM, Reuter VE, Eastham JA, et al. B7-H3 and B7x are highly expressed in human prostate cancer and associated with disease spread and poor outcome. Proc Natl Acad Sci USA. 2007;104(49):19458-63.

10. Assal A, Kaner J, Pendurti G, Zang X. Emerging targets in cancer immunotherapy: beyond CTLA-4 and PD-1. Immunotherapy. 2015;7(11):1169-86.

11. John P, Wei Y, Liu W, Du M, Guan F, Zang X. The B7x Immune Checkpoint Pathway: From Discovery to Clinical Trial. Trends Pharmacol Sci. 2019;40(11):883-96.

12. Podojil JR, Glaser AP, Baker D, Courtois ET, Fantini D, Yu Y, et al. Antibody targeting of B7-H4 enhances the immune response in urothelial carcinoma. Oncoimmunology. 2020;9(1):1744897.

13. Zhao LW, Li C, Zhang RL, Xue HG, Zhang FX, Zhang F, et al. B7-H1 and B7-H4 expression in colorectal carcinoma: correlation with tumor FOXP3(+) regulatory T-cell infiltration. Acta Histochem. 2014;116(7):1163-8.

14. Cao H, Wang Q, Gao Z, Xu X, Lu Q, Wu Y. Clinical value of detecting IQGAP3, B7-H4 and cyclooxygenase-2 in the diagnosis and prognostic evaluation of colorectal cancer. Cancer cell international. 2019;19:163-3.

15. Simon I, Zhuo S, Corral L, Diamandis EP, Sarno MJ, Wolfert RL, et al. B7-h4 is a novel membrane-bound protein and candidate serum and tissue biomarker for ovarian cancer. Cancer Res. 2006;66(3):1570-5.

16. Thompson RH, Zang X, Lohse CM, Leibovich BC, Slovin SF, Reuter VE, et al. Serum-soluble B7x is elevated in renal cell carcinoma patients and is associated with advanced stage. Cancer research. 2008;68(15):6054-8.

17. Xu CH, Wang W, Wang YC, Lin Y, Zhang XW. Diagnosis value of serum soluble B7-H4 expression in non-small cell lung cancer. Clin Respir J. 2018;12(1):134-9.

18. Wang P, Li C, Zhang F, Ma X, Gai X. Clinical Value of Combined Determination of Serum B7-H4 with Carcinoembryonic Antigen, Osteopontin, or Tissue Polypeptide-Specific Antigen for the Diagnosis of Colorectal Cancer. Dis Markers. 2018;2018:4310790.

19. Y. N. The role of protein kinase $\mathrm{C}$ in cell surface signal transduction and tumour promotion. Nature. 1984;308(5961):693-8.

20. Rosse C, Linch M, Kermorgant S, Cameron AJ, Boeckeler K, Parker PJ. PKC and the control of localized signal dynamics. Nat Rev Mol Cell Biol. 2010;11(2):103-12.

21. Verstovsek G, BA, Frey MR, Petrelli NJ, Black JD. Colonocyte differentiation is associated with increased expression and altered distribution of protein kinase C isozymes. Gastroenterology. 1998;115(1):75-85.

22. Black JD. Protein kinase $\mathrm{C}$ isozymes in colon carcinogenesis: guilt by omission. Gastroenterology. 2001;120(7):1868-72.

Page $12 / 20$ 
23. Wang J, Wu J, Hong J, Chen R, Xu K, Niu W, et al. PKC promotes the migration of colon cancer cells by regulating the internalization and recycling of integrin avß3. Cancer Lett. 2011;311(1):38-47.

24. Halvorsen AR, Haugen MH, Ojlert AK, Lund-Iversen M, Jorgensen L, Solberg S, et al. Protein Kinase C Isozymes Associated With Relapse Free Survival in Non-Small Cell Lung Cancer Patients. Front Oncol. 2020;10:590755.

25. Qvit N, Mochly-Rosen D. The many hats of protein kinase Cdelta: one enzyme with many functions. Biochem Soc Trans. 2014;42(6):1529-33.

26. Chen Z, Forman LW, Williams RM, Faller DV. Protein kinase C-delta inactivation inhibits the proliferation and survival of cancer stem cells in culture and in vivo. BMC Cancer. 2014;14:90.

27. Isakov N. Protein kinase C (PKC) isoforms in cancer, tumor promotion and tumor suppression. Semin Cancer Biol. 2018;48:36-52.

28. Reyland ME, Jones DNM. Multifunctional roles of PKCס: Opportunities for targeted therapy in human disease. Pharmacol Ther. 2016;165:1-13.

29. Hernández-Maqueda JG, Luna-Ulloa LB, Santoyo-Ramos P, Castañeda-Patlán MC, Robles-Flores M. Protein kinase $\mathrm{C}$ delta negatively modulates canonical Wnt pathway and cell proliferation in colon tumor cell lines. PloS one. 2013;8(3):e58540-0.

30. Cerda SR, Bissonnette M, Scaglione-Sewell B, Lyons MR, Khare S, Mustafi R, et al. PKC-delta inhibits anchoragedependent and -independent growth, enhances differentiation, and increases apoptosis in CaCo-2 cells. Gastroenterology. 2001;120(7):1700-12.

31. Pongracz J, Clark P, Neoptolemos JP, Lord JM. Expression of protein kinase C isoenzymes in colorectal cancer tissue and their differential activation by different bile acids. Int J Cancer. 1995;61(1):35-9.

32. Doller A, Winkler C, Azrilian I, Schulz S, Hartmann S, Pfeilschifter J, et al. High-constitutive HuR phosphorylation at Ser 318 by PKC\{delta\} propagates tumor relevant functions in colon carcinoma cells. Carcinogenesis. 2011;32(5):676-85.

33. Park M, Kim WK, Song M, Park M, Kim H, Nam HJ, et al. Protein kinase C-delta-mediated recycling of active KIT in colon cancer. Clin Cancer Res. 2013;19(18):4961-71.

34. André F, RV, Remacle-Bonnet M, Luis J, Pommier G, Marvaldi J. Protein kinases C-gamma and -delta are involved in insulin-like growth factor l-induced migration of colonic epithelial cells. Gastroenterology. 1999;116(1):64-77.

35. Kho DH, Bae JA, Lee JH, Cho HJ, Cho SH, Lee JH, et al. KITENIN recruits Dishevelled/PKC delta to form a functional complex and controls the migration and invasiveness of colorectal cancer cells. Gut. 2009;58(4):50919.

36. Mori Y, Akita K, Ojima K, Iwamoto S, Yamashita T, Morii E, et al. Trophoblast cell surface antigen 2 (Trop-2) phosphorylation by protein kinase C alpha/delta (PKCalpha/delta) enhances cell motility. J Biol Chem. 2019;294(30):11513-24.

37. Zhang L, Wu H, Lu D, Li G, Sun C, Song H, et al. The costimulatory molecule B7-H4 promote tumor progression and cell proliferation through translocating into nucleus. Oncogene. 2013;32(46):5347-58.

38. Bin Z, Guangbo Z, Yan G, Huan Z, Desheng L, Xueguang Z. Overexpression of B7-H3 in CD133 + colorectal cancer cells is associated with cancer progression and survival in human patients. J Surg Res. 2014;188(2):396-403.

39. Yao Y, Ye H, Qi Z, Mo L, Yue Q, Baral A, et al. B7-H4(B7x)-Mediated Cross-talk between Glioma-Initiating Cells and Macrophages via the IL6/JAK/STAT3 Pathway Lead to Poor Prognosis in Glioma Patients. Clin Cancer Res. 2016;22(11):2778-90.

40. Peters CA, Maizels ET, Robertson MC, Shiu RP, Soloff MS, Hunzicker-Dunn M. Induction of relaxin messenger RNA expression in response to prolactin receptor activation requires protein kinase $\mathrm{C}$ delta signaling. Mol Endocrinol. 
2000;14(4):576-90.

41. Gartsbein M, Alt A, Hashimoto K, Nakajima K, Kuroki T, Tennenbaum T. The role of protein kinase $C$ delta activation and STAT3 Ser727 phosphorylation in insulin-induced keratinocyte proliferation. J Cell Sci. 2006;119(Pt 3):47081.

42. Zhang X, Cai L, Zhang G, Shen Y, Huang J. B7-H4 promotes tumor growth and metastatic progression in lung cancer by impacting cell proliferation and survival. Oncotarget. 2017;8(12):18861-71.

43. Zhou D, Zhou Y, Li C, Yang L. Silencing of B7-H4 suppresses the tumorigenicity of the MGC-803 human gastric cancer cell line and promotes cell apoptosis via the mitochondrial signaling pathway. Int J Oncol. 2018;52(4):1267-76.

44. Li C, Zhan Y, Ma X, Fang H, Gai X. B7-H4 facilitates proliferation and metastasis of colorectal carcinoma cell through PI3K/Akt/mTOR signaling pathway. Clin Exp Med. 2020;20(1):79-86.

45. Xu Y, Zhu S, Song M, Liu W, Liu C, Li Y, et al. B7-H4 expression and its role in interleukin-2/interferon treatment of clear cell renal cell carcinoma. Oncol Lett. 2014;7(5):1474-8.

46. Kryczek I, Zou L, Rodriguez P, Zhu G, Wei S, Mottram P, et al. B7-H4 expression identifies a novel suppressive macrophage population in human ovarian carcinoma. J Exp Med. 2006;203(4):871-81.

47. Kryczek I, Wei S, Zhu G, Myers L, Mottram P, Cheng P, et al. Relationship between B7-H4, regulatory T cells, and patient outcome in human ovarian carcinoma. Cancer Res. 2007;67(18):8900-5.

48. Chen C, Qu QX, Shen Y, Mu CY, Zhu YB, Zhang XG, et al. Induced expression of B7-H4 on the surface of lung cancer cell by the tumor-associated macrophages: a potential mechanism of immune escape. Cancer Lett. 2012;317(1):99-105.

49. Zhao Z, Zhang N, Li A, Zhou B, Chen Y, Chen S, et al. Insulin-like growth factor-1 receptor induces immunosuppression in lung cancer by upregulating B7-H4 expression through the MEK/ERK signaling pathway. Cancer Lett. 2020;485:14-26.

50. Jeon YK1PS, Choi IW2, Lee SW3, Lee SM4, Choi I5. Cancer cell-associated cytoplasmic B7-H4 is induced by hypoxia through hypoxia-inducible factor-1a and promotes cancer cell proliferation. Biochem Biophys Res Commun. 2015;459(2):277-283.

51. Li QT, Qiu MJ, Yang SL, Fang X, He XX, Wang MM, et al. Alpha-Fetoprotein Regulates the Expression of ImmuneRelated Proteins through the NF-kappaB (P65) Pathway in Hepatocellular Carcinoma Cells. J Oncol. 2020;2020:9327512.

52. Zhou X, Mao Y, Zhu J, Meng F, Chen Q, Tao L, et al. TGF-beta1 promotes colorectal cancer immune escape by elevating B7-H3 and B7-H4 via the miR-155/miR-143 axis. Oncotarget. 2016;7(41):67196-211.

\section{Figures}


A

B7-H4
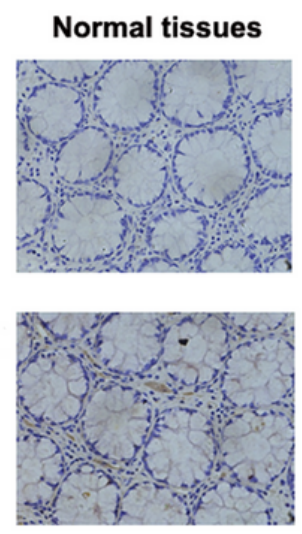

B

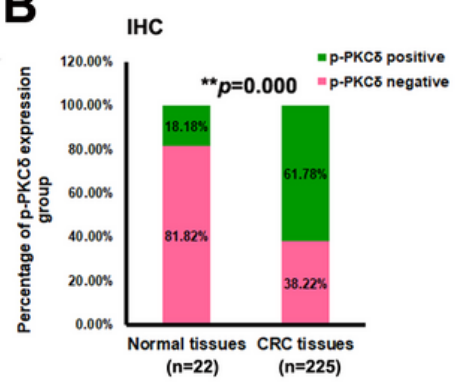

CRC tissues
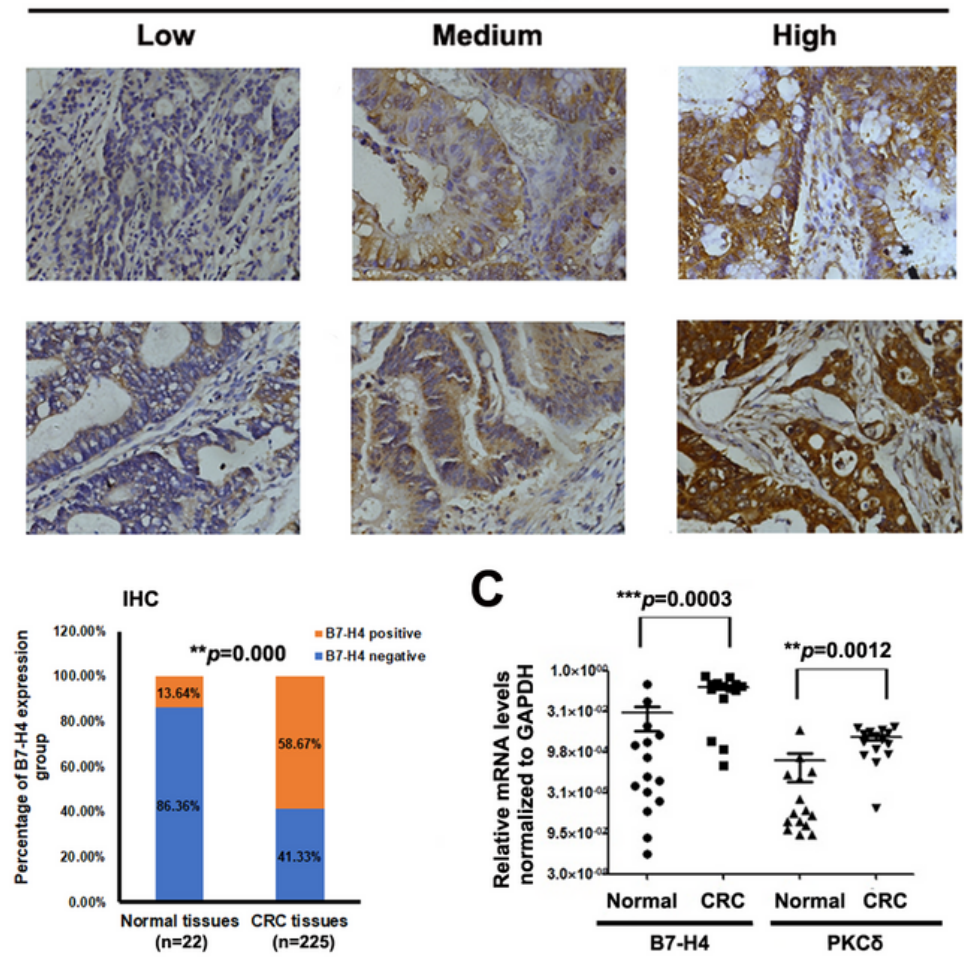

\section{Figure 1}

B7-H4 and p- PKCD levels were upregulated in clinical CRC tissue specimens. (A) Negative staining (400x) and low (400x), medium (400x), and high (400x) positive staining for B7-H4 and p- PKCס. (B) B7-H4 and p- PKCס levels were significantly increased in $\mathrm{CRC}$. The expression of $\mathrm{B} 7-\mathrm{H} 4$ and $\mathrm{p}-\mathrm{PKC} \delta$ in $\mathrm{CRC}$ tissue samples was compared with that in adjacent normal tissue samples. Statistical analysis was conducted with a paired $t$ test $(P<0.001)$. (C) Quantitative $\mathrm{PCR}$ analysis showed that the expression of both $\mathrm{B} 7-\mathrm{H} 4$ and $\mathrm{PKC} \delta$ was significantly increased in tumour tissue samples compared with adjacent normal colon tissue samples. 
A

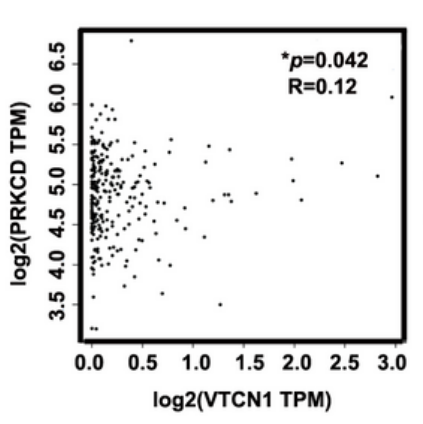

C

IHC

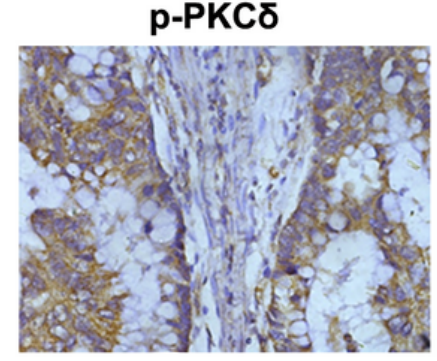

p-PKCס

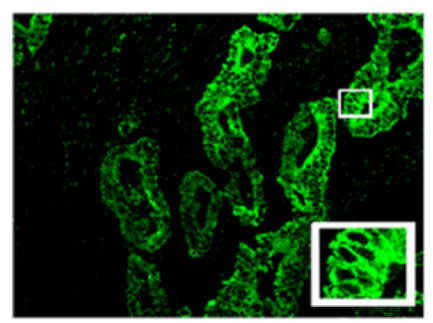

D

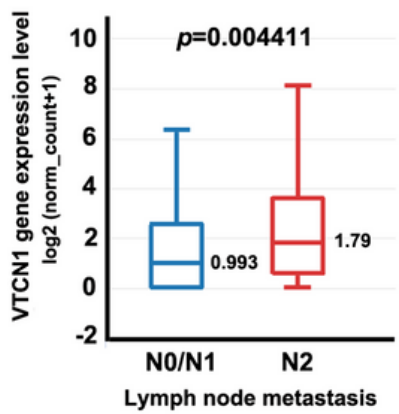

B
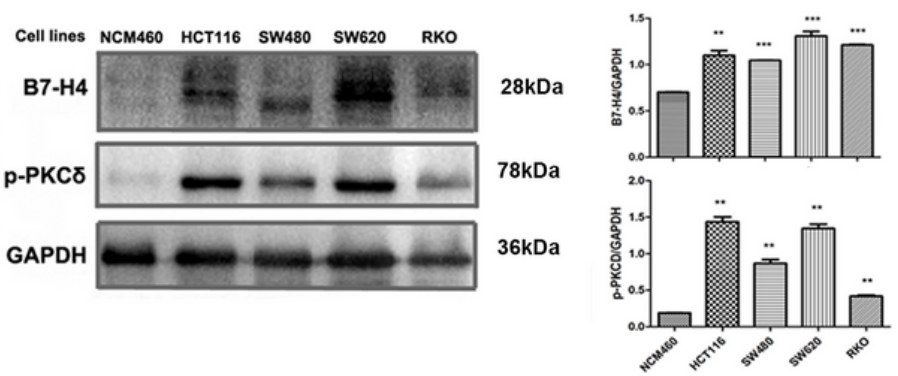

B7-H4

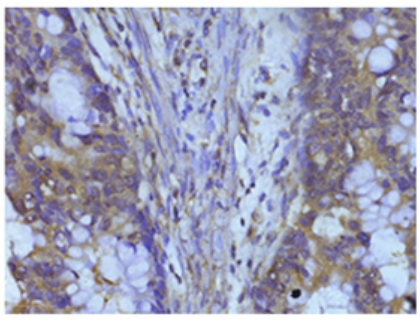

B7-H4
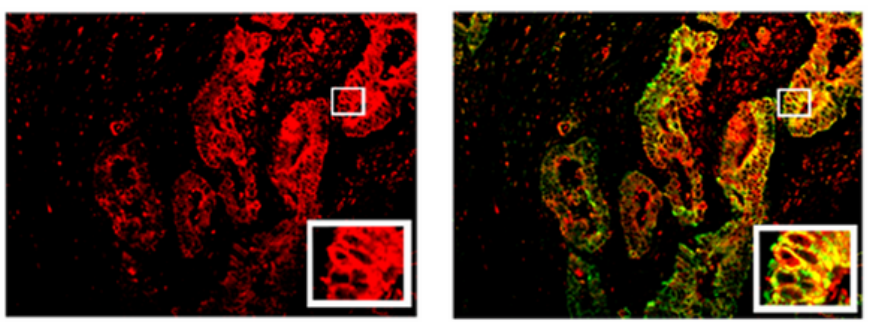

\section{Figure 2}

Correlation between B7-H4 and p- PKCס. (A) A TCGA dataset analysis performed on the GEPIA website (http://gepia.cancer-pku.cn/). This showed that PRKCD (PKCD) mRNA expression was positively correlated with VTCN1 (B7-H4 gene) mRNA levels. (B) The protein levels of B7-H4 and p- PKCס in the NCM460, SW480, HCT116, SW620 and RKO cell lines were determined by Western blot analysis. Data are expressed as the mean \pm SD, $n=3$. (C) Serial p- PKC + tumour sections were examined for B7-H4 expression, and positive staining (400x) for B7-H4 and positive staining (400x) for $\mathrm{p}$ - PKC $\delta$ in CRC samples are shown. IF double staining of CRC samples was performed. CRC tissue samples were stained for p-PKC (green, 200x) and B7-H4 (red, 200x). B7-H4+/p- PKC + cells were identified in CRC tissue specimens (dark yellow; original magnifications). (D) A TCGA COAD dataset analysis performed on the XENA website showed that the B7-H4 mRNA level was positively correlated with lymph node metastasis. 
A
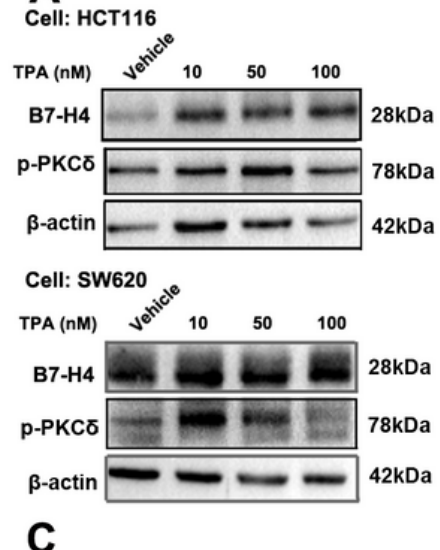

C
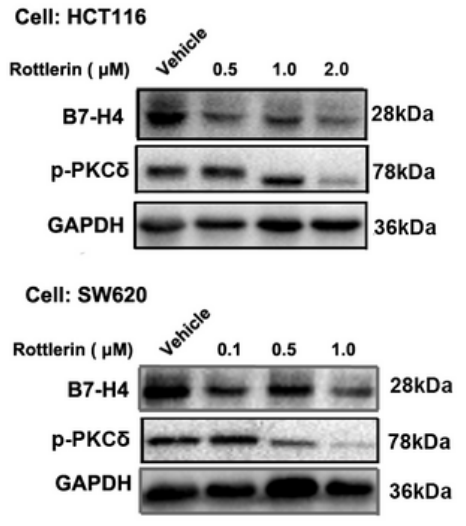

E

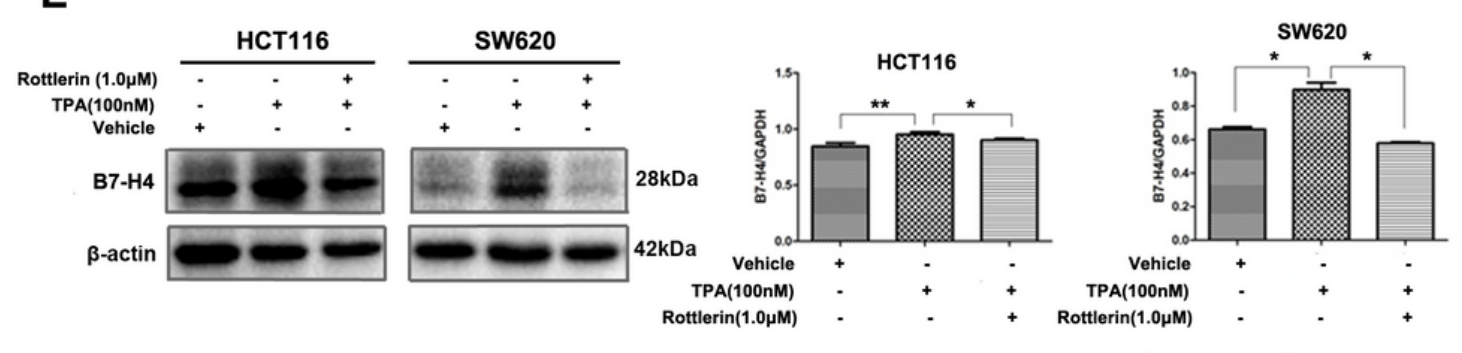

B Cell: HCT116
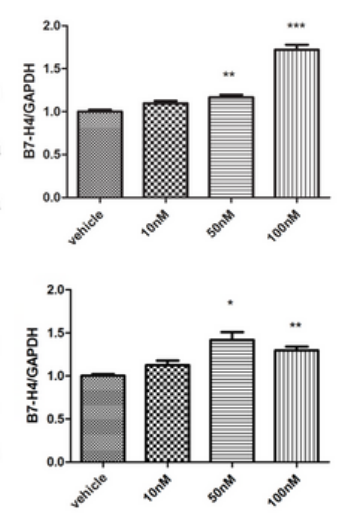

$48 h$

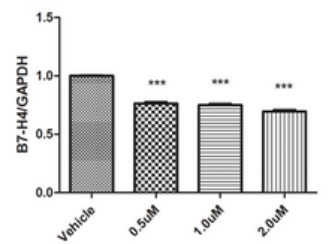

D
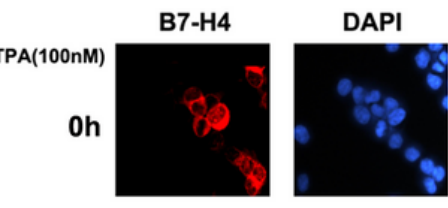

Merge
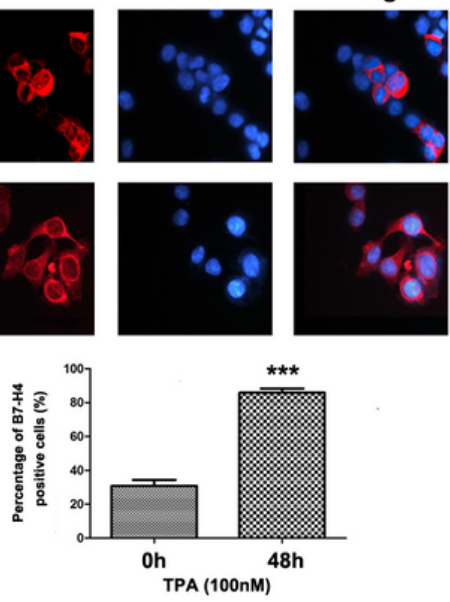

Cell: HCT116
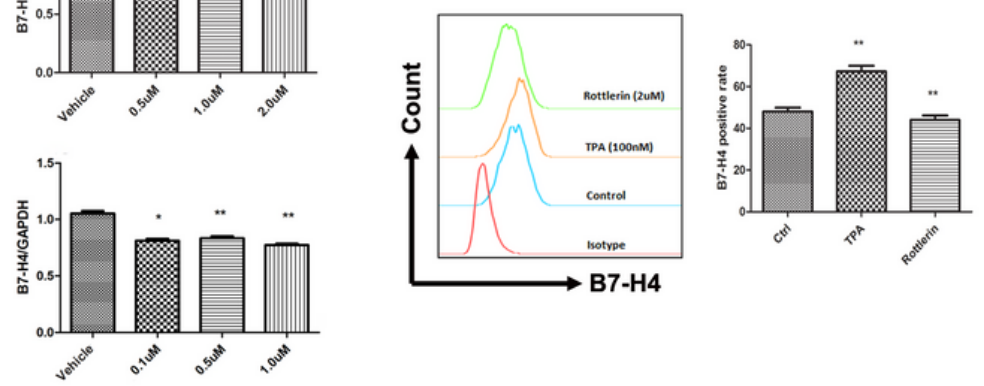

B7-H4
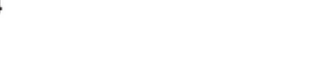
A
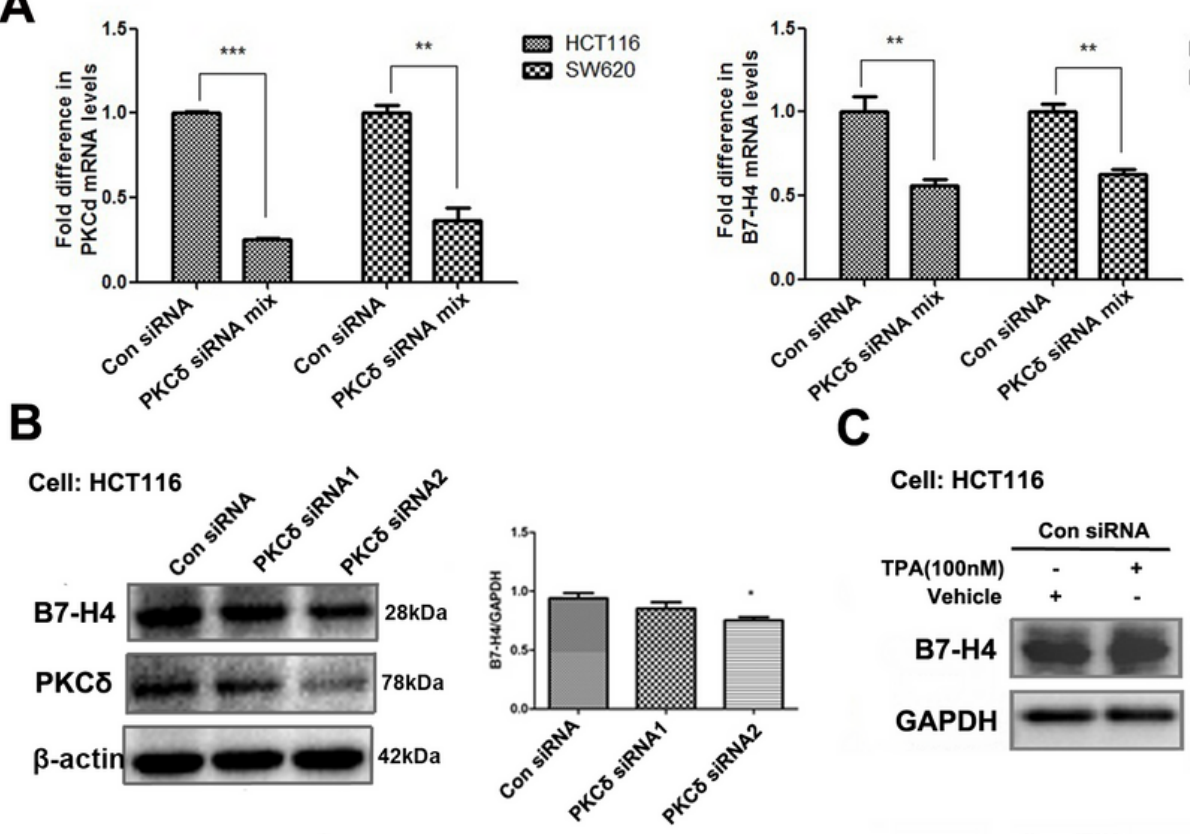

HCT116

Cell: HCT116
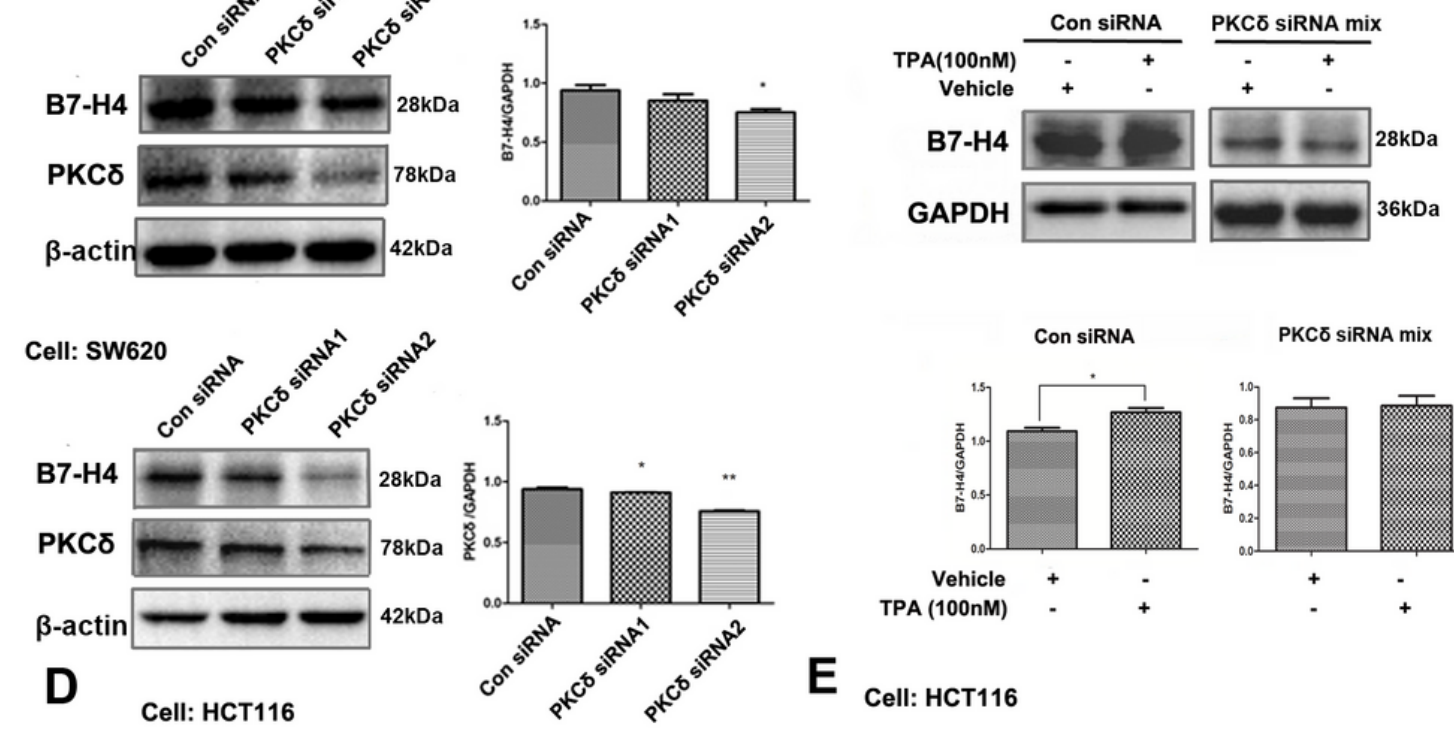

PKCס siRNA mix
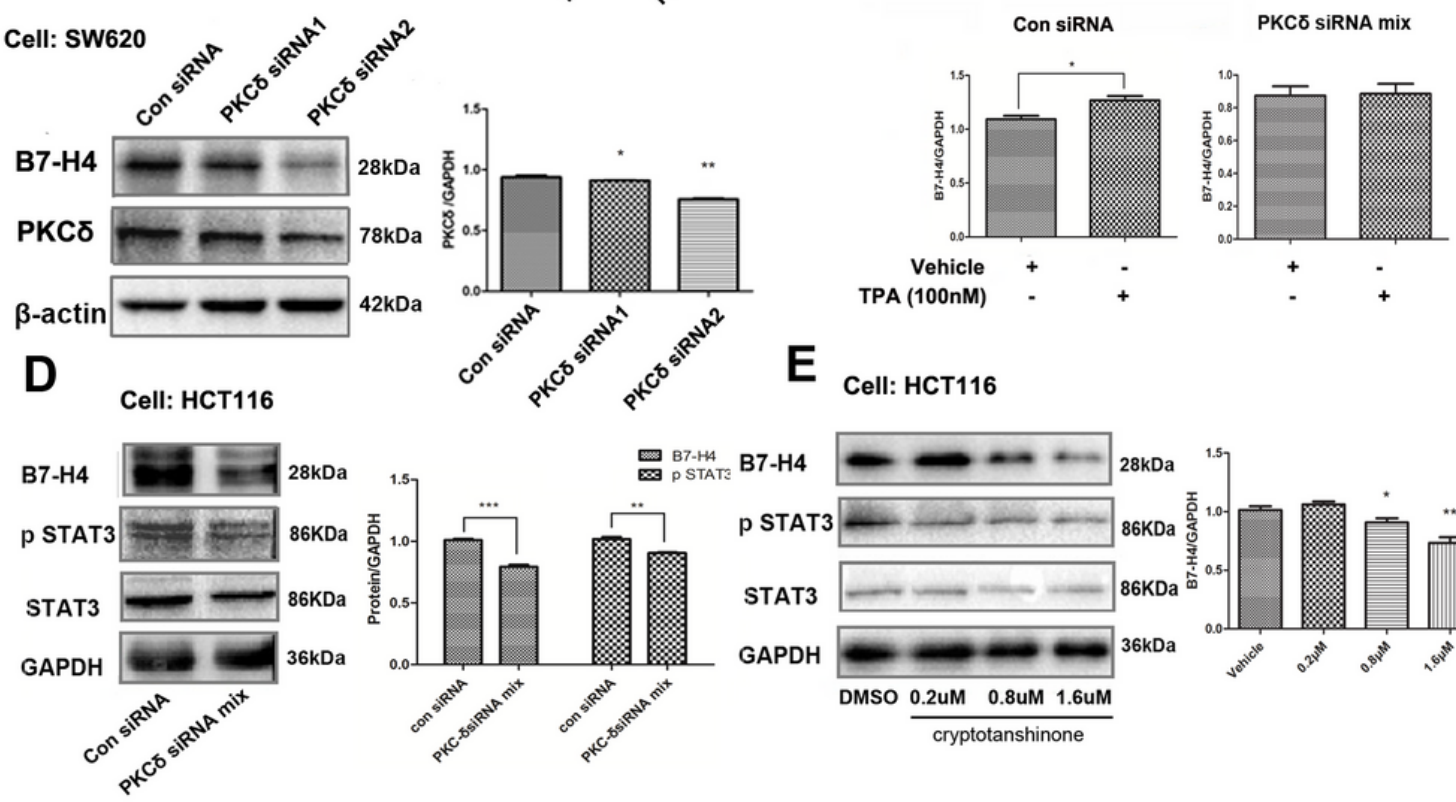

E Cell: HCT116

\section{Figure 4}

PKCס inhibited B7-H4 expression via STAT3 in CRC cell lines. HCT116 and SW620 cells were treated with PKCD-specific siRNA for 45 h. B7-H4 and PKCס levels were determined by quantitative RT-PCR (A) and Western blotting (B). HCT116 cells were treated with PKC - -specific siRNA for $24 \mathrm{~h}$ and then incubated with TPA (100 nM) for $20 \mathrm{~h}$ (C). PKC $\delta$ siRNA treatment reduced both the expression of B7-H4 and STAT3 in HCT116 cells (D). HCT116 was treated with various concentrations of STAT3 inhibitor cryptotanshinone (E) for $24 \mathrm{~h}$. The cells were harvested to generate whole-cell lysates for detection of the indicated proteins by Western blot analysis. A representative Western blot and data for B7$\mathrm{H} 4$ expression (mean \pm SEM) from three separate experiments are shown. ${ }^{*} \mathrm{P}<0.05, * \star \mathrm{P}<0.01$ and $* \star * P<0.001$. 
A

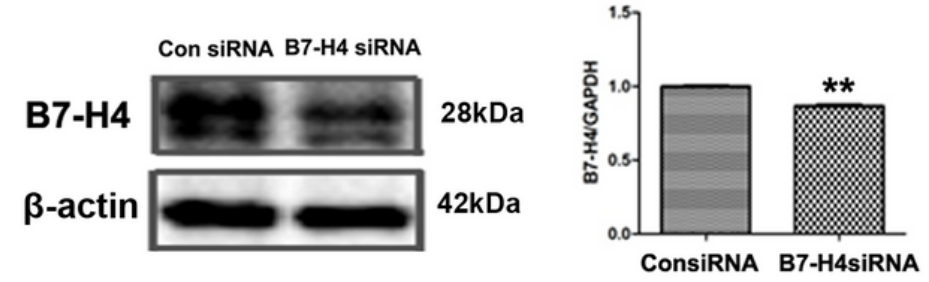

B
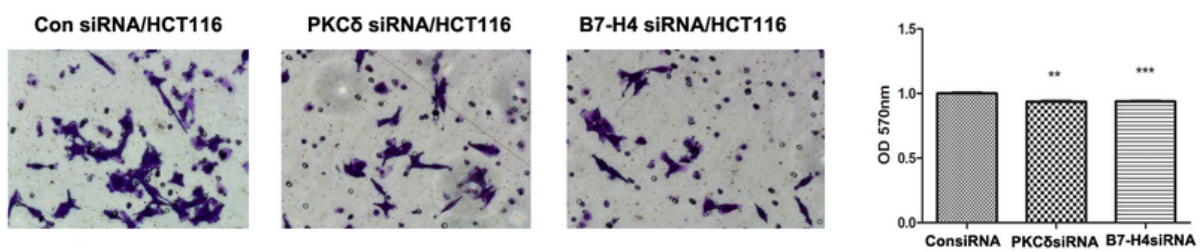

C
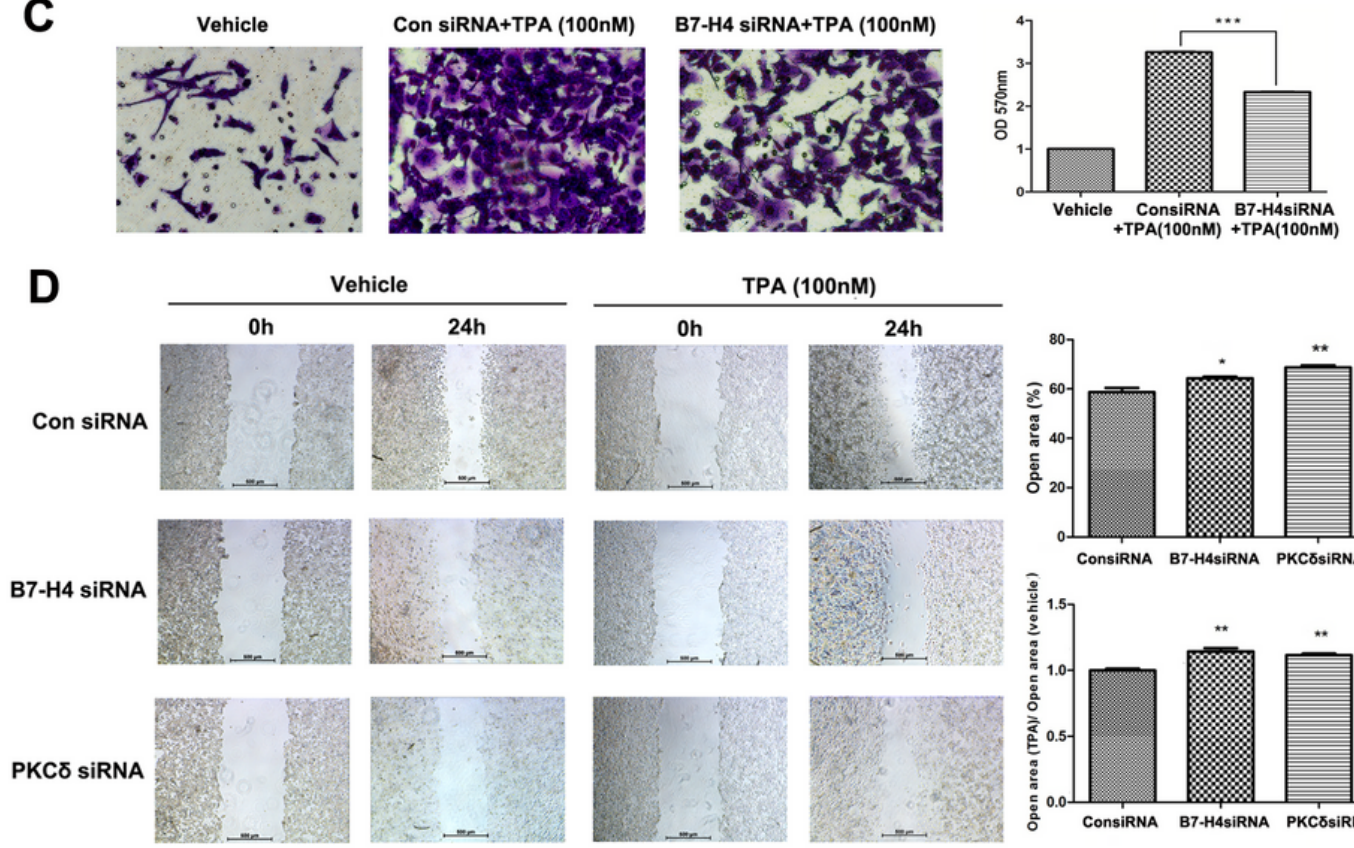

PA (100nM)
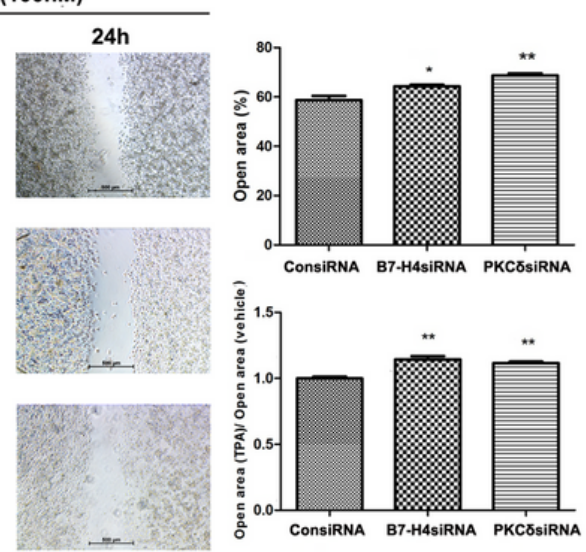

\section{$\mathbf{E}$}

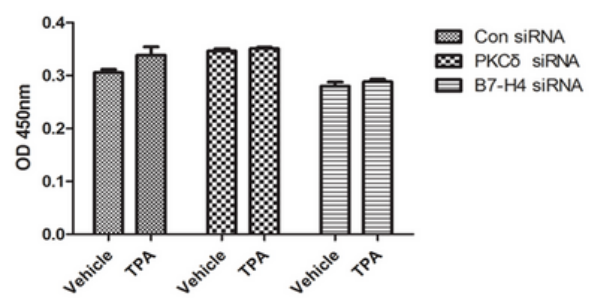

\section{Figure 5}

The PKCD/B7-H4 axis promotes the migration of HCT116 cells. HCT116 cells were treated with B7-H4-specific siRNA for $45 \mathrm{~h}$, and then $\mathrm{B} 7-\mathrm{H} 4$ protein levels were determined by Western blot analysis (A). A Transwell experiment examined the constitutive invasion of B7-H4 siRNA/HCT116, PKCס siRNA/HCT116 and con siRNA/HCT116 cells (B). The invasion of B7-H4 siRNA/HCT116 cells was evaluated after the cells were treated with $100 \mathrm{nM}$ TPA for $24 \mathrm{~h}$ (C). A wound-healing experiment was performed to evaluate the effects of PKC $\delta$ and $\mathrm{B} 7-\mathrm{H} 4$ on cell migration (D). The cell viability was assessed by CCK-8 (E). Every group of cells was treated with $100 \mathrm{nM}$ TPA or vehicle for $24 \mathrm{~h}$. Experiments were performed in triplicate. ${ }^{*} \mathrm{P}<0.05,{ }^{*} \mathrm{P}<0.01$ and $* \star * \mathrm{P}<0.001$.

\section{Supplementary Files}


This is a list of supplementary files associated with this preprint. Click to download.

- SupplementalTable1.docx 